\title{
Effect of Menstrual Cycle Phase on Dopamine D2 Receptor Availability in Female Cynomolgus Monkeys
}

\author{
Paul W Czoty', Natallia V Riddick', H Donald Gage ${ }^{2}$, Mikki Sandridge', Susan H Nader', Sudha Garg', \\ Michael Bounds', Pradeep K Garg ${ }^{2}$ and Michael A Nader*,1,2 \\ 'Department of Physiology and Pharmacology, Wake Forest University School of Medicine, Winston-Salem, NC, USA; '2Department of Radiology, \\ Wake Forest University School of Medicine, Winston-Salem, NC, USA
}

\begin{abstract}
Sex differences have been reported in a variety of affective and neurodegenerative disorders that involve dysfunctional dopamine (DA) neurotransmission. In addition, there is evidence for differences in sensitivity to the abuse-related effects of psychostimulants across the menstrual cycle which may result from effects of ovarian hormones on DA function. The goal of the present study was to extend previous work examining menstrual cycle-related changes in DA D2 receptor availability in humans to drug-naive female cynomolgus monkeys $(n=7)$ using the selective D2-like receptor ligand $\left[{ }^{18} \mathrm{~F}\right]$ fluoroclebopride (FCP) and a high-resolution microPET P4 scanner. Menstrual cycle phase was characterized by daily vaginal swabs and measurements of serum progesterone levels. PET studies were conducted once during the luteal phase and once during the follicular phase. Regions of interest in the caudate nucleus, putamen, and cerebellum were defined on coregistered MRIs. Distribution volumes were calculated for FCP in each structure and the distribution volume ratio (DVR) for both brain regions relative to the cerebellum was used as a measure of D2 receptor availability. FCP DVRs were significantly higher in the luteal phase compared to the follicular phase in both the caudate nucleus $(11.7 \%$ difference, $p=0.02)$ and putamen (1 $1.6 \%$ difference, $p=0.03$ ). These findings extend earlier work in humans and suggest that changes in DA receptor availability may be involved in the variation in symptoms of various neuropsychiatric disorders across the menstrual cycle, including differences in sensitivity to the abuse-related effects of stimulants.
\end{abstract}

Neuropsychopharmacology (2009) 34, 548-554; doi: I0.1038/npp.2008.3; published online 6 February 2008

Keywords: dopamine receptor; menstrual cycle; progesterone; non-human primates; microPET; caudate nucleus

\section{INTRODUCTION}

Sex differences have been demonstrated in the incidence and progression of, as well as medication effectiveness in, several neuropsychiatric disorders, including Parkinson's disease, schizophrenia, obsessive-compulsive disorder, and drug abuse (eg Seeman, 1996; Bogetto et al, 1999; Cyr et al, 2002; Wieck et al, 2003; Lynch et al, 2002; Lynch, 2006). Dysfunction of brain dopamine (DA) systems, particularly the D2-like superfamily of DA receptors, has been associated with these conditions (Cross et al, 1981; Guttman and Seeman, 1985; Volkow et al, 1993; Hesse et al, 2005). Thus, sex differences in the course and treatment of these disorders may be mediated by differences in dopaminergic function in brain areas affected by these disorders, including striatal regions (eg Munro et al, 2006). One mediator of these differences could be gonadal hormones

* Correspondence: Dr MA Nader, Department of Physiology and Pharmacology, Wake Forest University School of Medicine, Medical Center Boulevard, 546 NRC, Winston-Salem, NC 27I57-I083, USA, Tel: + I 336713 7172, Fax: + I 3367137180 ,

E-mail: mnader@wfubmc.edu

Received 14 July 2007; revised 5 December 2007; accepted 15 December 2007 which have been shown to affect brain DA systems in laboratory animals (eg Pazos et al, 1985; Di Paolo et al, 1988; Bazzett and Becker, 1994). Although the vast majority of these studies have used rodent subjects, consistent findings have been reported in non-human primates. For example, DA neuron densities in the substantia nigra were higher in intact female monkeys compared to males or ovariectomized females (Leranth et al, 2000).

In apparent contrast to these findings in animals, researchers using brain imaging techniques in humans have reported either modest or no sex differences in basal D2 receptor availability in subcortical brain areas (Farde et al, 1995; Pohjalainen et al, 1998; Munro et al, 2006). In these studies, the lack of robust sex differences may be due to effects of menstrual phase-related fluctuations in estrogen and/or progesterone on PET measures. Studies in rodents using receptor autoradiography have demonstrated that $\mathrm{D} 2$ receptor densities can increase in the presence of natural elevations in estrogen during the estrous cycle and after exogenous estrogen administration (Pazos et al, 1985; Bazzett and Becker, 1994; see Di Paolo, 1994). Moreover, in women, behavioral effects of drugs of abuse such as amphetamine and cocaine, which primarily act on brain DA systems, differ as a function of menstrual cycle phase 
(eg Justice and de Wit, 1999; Sofuoglu et al, 1999; Evans et al, 2002; White et al, 2002; Evans and Foltin, 2006; for review see Terner and de Wit, 2006). Studies using positron emission tomography (PET) have documented fluctuations in $5-\mathrm{HT}_{1 \mathrm{~A}}$ receptors and glucose utilization across the menstrual cycle (Reiman et al, 1996; Jovanovic et al, 2006) as well as correlations between circulating levels of ovarian hormones and measures of $\mu$ opiate receptor binding (Smith et al, 1998). Three studies have assessed D2 receptor availability as a function of menstrual cycle. Wong et al (1988) observed a trend toward lower striatal uptake of the D2 ligand $\left[{ }^{11} \mathrm{C}\right]-N$-methyl-spiperone (NMSP) in the follicular vs luteal phase, indicating either lower D2 receptor densities or higher striatal DA concentrations during the follicular phase. More recently, this group observed lower baseline binding potential for $\left[{ }^{11} \mathrm{C}\right]$ raclopride in the putamen (but not caudate nucleus or ventral striatum) in women in the luteal $v s$ follicular phase (Munro et al, 2006). In contrast, Nordström et al (1998) observed no menstrual cycle-dependent variations in D2 receptor availability in the putamen using $\left[{ }^{11} \mathrm{C}\right]$ raclopride in five women. Thus, the scant available evidence suggests that differences in D2 receptor availability may influence symptoms and effects of drugs observed across the menstrual cycle (for reviews see Seeman and Lang, 1990; Hendrick et al, 1996; Terner and de Wit, 2006).

Most preclinical studies examining effects of ovarian hormones on DA and D2 receptor function have been conducted in rodents. Unlike rodents, which have a 4-day estrous cycle, the menstrual cycle of Old World macaques is similar to humans, with a duration of approximately 28 days and well-characterized fluctuations in estrogen and progesterone (Jewitt and Dukelow, 1972; Goodman et al, 1977; Appt, 2004). The primary purpose of the present study was to extend research on menstrual cycle phase and D2 receptor availability to non-human primates. Whereas the three human PET studies used two different radiotracers and examined different brain regions, we used a single radioligand to examine both caudate nucleus and putamen. Moreover, the present studies used drug-naive animals, a within-subjects design and a high-resolution $(\sim 2 \mathrm{~mm})$ microPET camera.

\section{MATERIALS AND METHODS}

\section{Subjects}

Seven experimentally naive female cynomolgus monkeys (Macaca fascicularis) aged 9-17 years served as subjects. Monkeys were naive to drugs with the exception of infrequent (less than once per month) exposure to ketamine used as an anesthetic to facilitate veterinary or imaging procedures. Each monkey lived individually in a stainless steel cage $(0.71 \times 0.84 \times 0.84 \mathrm{~m}$; Allentown Caging Co., Allentown, PA). Monkeys' body weights were maintained at approximately $95 \%$ of their free-feeding weights by limiting daily access to food (LabDiet No 5038 Monkey Chow and fresh fruit); animals had unlimited access to water. Animal housing, handling and all experimental procedures were performed in accordance with the 2003 National Research Council Guidelines for the Care and Use of Mammals in Neuroscience and Behavioral Research and were approved by the Animal Care and Use Committee of Wake Forest University. Environmental enrichment was provided as outlined in the Animal Care and Use Committee of Wake Forest University Non-Human Primate Environmental Enrichment Plan.

\section{Menstrual Phase Determination}

Menstrual cycle duration was assessed initially by daily vaginal swabs over several months. Days of bleeding were recorded as indicative of menses. Once a cycle of approximately 28 days had been observed, PET scans were scheduled to occur during the subsequent follicular and luteal phases. To confirm cycle phase, on the day of a PET study $3 \mathrm{ml}$ of blood was drawn from the femoral vein. The blood was centrifuged (Beckman Coulter, GPR Centrifuge) at 3000 r.p.m. and $4^{\circ} \mathrm{C}$ for $30 \mathrm{~min}$. The serum was then aspirated into an Eppendorf tube and stored at $-20^{\circ} \mathrm{C}$. Progesterone assays were performed at the Biomarkers Core Laboratory of the Yerkes National Primate Research Center of Emory University in Atlanta, GA. Progesterone levels were measured using a commercially available kit from Diagnostic Products Corporation (Los Angeles, CA) using a modification of a previously described assay (Wilson, 1998). Samples $(250 \mu \mathrm{l})$ were extracted with $2.5 \mathrm{ml}$ of anesthesiagrade ether and the organic layer was evaporated to dryness under a stream of $\mathrm{N}_{2}$. The sample was reconstituted in $250 \mu \mathrm{l}$ of the assay buffer and $100 \mu \mathrm{l}$ replicates were assayed. This assay has a sensitivity of $0.1 \mathrm{ng} / \mathrm{ml}$ with an intra-assay coefficient of variation of $8.44 \%$ and an inter-assay coefficient of $8.14 \%$ across the range of the standard curve.

\section{MR and PET Imaging}

Magnetic resonance images (MRI) were acquired for each monkey. Approximately $20 \mathrm{~min}$ prior to the study, subjects were anesthetized with ketamine $(15 \mathrm{mg} / \mathrm{kg}$, i.m.) and transported to the MRI facility. Anesthesia was maintained during the scanning procedure with ketamine supplements when necessary. 3D SPGR brain images were acquired (TE 5, TR 45, flip angle 45, RBW $15.6 \mathrm{kHz}$, FOV $18 \mathrm{~cm}, 256 \times 192$ matrix, slice thickness $2 \mathrm{~mm}$, NEX 3) with a 1.5-Tesla GE Signa NR scanner (GE Medical Systems). T1-weighted whole brain images were used to anatomically define spherical regions of interest (ROIs), including the right and left caudate nucleus, putamen ( $0.5 \mathrm{~mm}$ radius), and cerebellum ( $0.8 \mathrm{~mm}$ radius), for later co-registration with PET images.

PET scans to measure D2 receptor availability using the D2 receptor radioligand $\left[{ }^{18} \mathrm{~F}\right]$ fluoroclebopride (FCP) were conducted twice in each monkey, once in the follicular phase and once in the luteal phase. Follicular phase scans were scheduled on days 5-12 of the menstrual cycle and luteal scans on days 21-26, with the exception of one subject (Table 1); this variability in cycle day was due primarily to logistical issues (ie the PET camera was unavailable due to weekends or use by other investigators). The phase in which each monkey was first scanned was counterbalanced. It should be noted that FCP does not differentiate among subtypes of the D2-like superfamily (ie $\mathrm{D}_{2}, \mathrm{D}_{3}$, and $\mathrm{D}_{4}$ receptors; see Mach et al, 1996). Prior to each study, monkeys were anesthetized with $10 \mathrm{mg} / \mathrm{kg}$ ketamine and transported to the PET Center. This dose of ketamine does 
not affect D2 receptor availability as measured with FCP (Nader et al, 1999). Details regarding the PET data acquisition protocol, blood sampling procedure, and metabolite analysis have been fully described previously (Mach et al, 1996, 1997; Morgan et al, 2002; Nader et al, 1999). An arterial and a venous catheter were inserted by percutaneous stick for blood sampling and tracer injection, respectively. A paralytic agent $(0.07 \mathrm{mg} / \mathrm{kg}$ vecuronium $\mathrm{Br}$, i.v.) was administered and ventilation was maintained by a respirator throughout the 3-h PET study. Supplemental doses of vecuronium $(0.1 \mathrm{mg} / \mathrm{h})$ were administered throughout the study. Body temperature was maintained at $40^{\circ} \mathrm{C}$ and vital signs (heart rate, blood pressure, respiration rate, and temperature) were monitored throughout the scanning procedure. The time between the two scans ranged between 12 and 66 days; over this period average weight change was minimal $(0.03 \mathrm{~kg})$.

PET scans were acquired using a primate microPET P4 scanner (Siemens/CTI Concorde) specifically designed for small-animal imaging. This scanner has a $7.8-\mathrm{cm}$ axial extent, a $19-\mathrm{cm}$ diameter transaxial field of view, and a $22-\mathrm{cm}$ animal port. In a single scan, the microPET provides 63 transverse slices with a $1.2-\mathrm{mm}$ center-to-center spacing over the axial field of view. The reconstructed resolution is approximately $2.2 \mathrm{~mm}$ in all three axes. (For additional information on scanner performance, see Tai et al, 2001; Fahey et al, 2004).

$\left[{ }^{18} \mathrm{~F}\right] \mathrm{FCP}$ was synthesized as described previously (Mach et al, 1993a, b). At the start of the PET scan, approximately $4 \mathrm{mCi}$ of $\left[{ }^{18} \mathrm{~F}\right] \mathrm{FCP}$ was injected, followed by $3 \mathrm{ml}$ of heparinized saline. At appropriate times, arterial blood samples were withdrawn and placed into preheparinized minicentrifuge tubes for analysis (see Mach et al, 1997 for complete details). Scans were conducted and images were registered to each subjects' MRI (for details see Czoty et al, 2005). Tissue-time-activity curves were generated, and distribution volumes were obtained for each ROI using the linear portion of the Logan plot (Logan et al, 1990). Distribution volume ratios (DVRs) for the caudate nucleus and putamen were calculated using the cerebellum as the reference region. DVR thus served as an index of specific $\left[{ }^{18} \mathrm{~F}\right]$ FCP binding in each ROI. Note that we used DVR as the primary dependent variable; others have used binding potential, which can be obtained by the formula DVR-1.

Table I Plasma Progesterone Levels $(\mathrm{ng} / \mathrm{ml})$ at Time of PET Study in Each Monkey as a Function of Menstrual Cycle Phase

\begin{tabular}{lclllc}
\hline Subject & Age (years) & Phase (day) & PG & Phase & PG \\
\hline C-6804 & 15 & Follicular (I I) & 1.94 & Luteal (26) & 4.57 \\
C-7370 & 13 & Follicular (10) & 0.54 & Luteal (23) & 10.82 \\
C-7374 & 10 & Follicular (I2) & 1.72 & Luteal (21) & 18.50 \\
C-68I2 & 17 & Follicular (I I) & 1.83 & Luteal (23) & 9.55 \\
C-7376 & 15 & Follicular (8) & 0.13 & Luteal (21) & 9.76 \\
C-7377 & 9 & Follicular (5) & 0.73 & Luteal (22) & 4.21 \\
C-6820 & 9 & Follicular (9) & 3.48 & Luteal (58) & 4.34 \\
MEAN (SEM) & $12.4(1.3)$ & $9.4(1.0)$ & $1.5(0.5)$ & $22.7(0.8)$ & $8.8(2.1)$ \\
\hline
\end{tabular}

aLuteal phase PET study was conducted on day 58 because this monkey skipped a menstrual cycle period. Day 58 was not included in the calculation of mean length of menstrual cycle for the group.

\section{Data Analysis}

Paired $t$-tests were used to compare DVRs for each brain region separately. Average levels of progesterone obtained in luteal and follicular phases were also compared using a paired $t$-test. In all cases, significance was accepted at the $95 \%$ level of confidence $(p<0.05)$.

\section{RESULTS}

Initial characterization indicated that menstrual cycles ranged from 28 to 30 days across animals; bleeding was typically detected on 4 days of the cycle (range: 2-6 days). Blood samples taken on days of PET scans confirmed that monkeys were in the calculated phase. On average, PET scans were conducted on day 9 (follicular phase) and day 23 (luteal phase, Table 1) of the menstrual cycle. Plasma progesterone concentrations differed significantly $(p<0.05)$ between follicular and luteal phases (Table 1).

As has been described previously for this radiotracer, there was a high level of uptake of $\left[{ }^{18} \mathrm{~F}\right] \mathrm{FCP}$ and a linear rate of washout from all regions of interest. In the reference region, the cerebellum, there was a low level of $\left[{ }^{18} \mathrm{~F}\right] \mathrm{FCP}$ uptake and rapid rate of washout. Importantly, the distribution volumes in the cerebellum did not change significantly as a function of menstrual cycle phase (data not shown). For all structures assessed, there were no differences between left and right sides, so mean data are shown (Figure 1$)$. In the caudate nucleus the mean $( \pm$ SEM) FCP DVR during the follicular phase $(2.85 \pm 0.11)$ was significantly lower than during the luteal phase $(3.18 \pm 0.14$; $\left.t_{6}=3.16, p=0.020\right)$. Similarly, in the putamen the mean DVR during the follicular phase $(3.07 \pm 0.14)$ was significantly lower than during the luteal phase $(3.42 \pm 0.18$; $\left.t_{6}=2.79, p=0.032\right)$. The relative differences in mean $\left[{ }^{18} \mathrm{~F}\right]$ FCP DVR values observed in the caudate nucleus and putamen averaged 11.7 and 11.6 percent, respectively

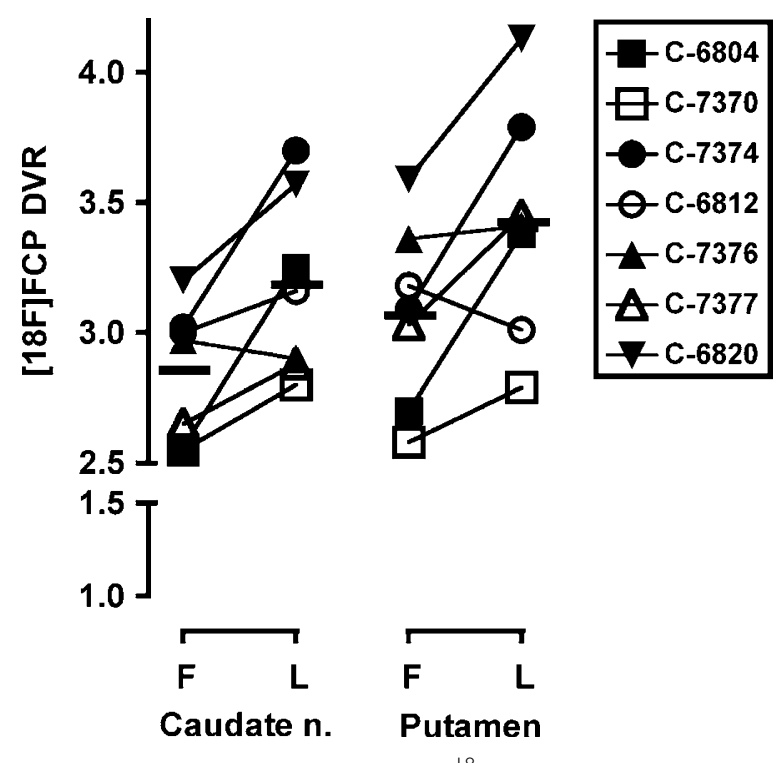

Figure I Effects of menstrual cycle on $\left[{ }^{18} \mathrm{~F}\right] \mathrm{FCP}$ DVR in caudate nucleus and putamen relative to the cerebellum. Each monkey was scanned once in follicular (F) and luteal (L) phases. Horizontal lines indicate group means. 
(Table 2). Importantly, despite the relatively large range of days used to define follicular (cycle day 5-12) and luteal (day 21-26), within a cycle, neither DVRs nor progesterone levels varied as a function of the day on which the scan occurred. DVRs were also measured in the anterior cingulate cortex, but the very low $\left[{ }^{18} \mathrm{~F}\right] \mathrm{FCP}$ binding observed in this region (follicular and luteal phase DVRs averaged $1.19 \pm 0.05$ and $1.24 \pm 0.05$, respectively) rendered this ligand unsuitable for assessment of cycle-related fluctuations in D2 receptor availability in this region.

\section{DISCUSSION}

The present study used a within-subjects design to examine whether menstrual cycle phase influenced D2 receptor availability in drug-naive female cynomolgus monkeys. As in humans, the menstrual cycle in female macaques was observed to last approximately 28 days; the appropriate phase was confirmed in this study by measuring plasma progesterone levels on the days PET scans were conducted. Measures of D2 receptor availability were approximately $12 \%$ higher in the luteal phase compared to the follicular phase in the caudate nucleus and putamen, a degree of variation that is well outside the reported between-studies variability of FCP (approximately 2\%; Nader et al, 1999). These findings suggest that menstrual cycle can influence striatal DA receptor availability, which may be a neurobiological mechanism underlying menstrual cycle-related changes in symptoms and clinical efficacy for treatments of neurodegenerative and affective disorders (eg Tolson et al, 2002; Terner and de Wit, 2006).

A characteristic of PET ligands with reversible binding kinetics, including FCP (Mach et al, 1997), is the ability of the radiotracer to be displaced by extracellular DA (eg Dewey et al, 1992; Ginovart et al, 1997; see Laruelle, 2000; Nader and Czoty, 2008). Thus, the observed changes in $\left[{ }^{18}\right.$ F]FCP DVRs across the menstrual cycle may be due to changes in D2 receptor numbers, fluctuations in levels of extracellular DA or both. In the present study, we confirmed menstrual cycle phase by measuring progesterone levels, which were significantly higher in the luteal compared to follicular phase. In contrast, estrogen levels are high during the follicular phase. Thus, one mechanism for the lower D2 DVRs in the follicular phase may be related to increases in DA release produced by high levels of estrogen (Becker et al, 2001; Dazzi et al, 2007; Di Paolo et al, 1986; for review

Table 2 Percent Changes in $\left[{ }^{18} \mathrm{~F}\right] \mathrm{FCP}$ DVR from Follicular to Luteal Phase

\begin{tabular}{lcc}
\hline Subject & Caudate nucleus & Putamen \\
\hline C-6804 & 26.8 & 25.4 \\
C-7370 & 10.0 & 8.2 \\
C-7374 & 22.5 & 22.7 \\
C-6812 & 4.8 & -5.8 \\
C-7376 & -2.4 & 1.5 \\
C-7377 & 8.5 & 13.9 \\
C-6820 & 11.6 & 15.2 \\
MEAN (SEM) & $11.7(4.1)$ & $11.6(4.6)$ \\
\hline
\end{tabular}

see Becker, 1999). Future studies using in vivo microdialysis or PET imaging studies that measure displacement of a D2 ligand after acute estrogen administration will better determine the precise role of this hormone in $\mathrm{D} 2$ receptor availability. The second possibility, that D2 receptor densities changed between the follicular and luteal phases, is less likely. Studies in rodents examining effects of estrogen on D2 receptor densities have produced mixed results. Administration of estradiol benzoate $(20 \mu \mathrm{g} / \mathrm{kg})$ significantly decreased striatal D2 receptor densities in the caudal striatum of ovariectomized rats (Bazzett and Becker, 1994). In contrast, estrogen increased striatal D2 receptor densities (for review see Di Paolo, 1994). Also in rats, Di Paolo et al (1988) reported that the ratio of high/low affinity states of striatal D2 receptors was highest when estrogen levels were low (the rat diestrus) and lowest when estrogen levels were high (the rat proestrus). Adding further complexity, most of these studies have been conducted in ovariectomized animals, and thus are perhaps a better model of changes accompanying menopause than menstrual cycle fluctuations. Comparable receptor density studies have not been conducted in intact, normally cycling female monkeys.

The present data documenting differences in D2 receptor availability across menstrual cycle phases extends two earlier findings in women (Wong et al, 1988; Munro et al, 2006) and contrasts with a third (Nordström et al, 1998). Wong et al (1988) measured the binding rate constant (termed k3) in the caudate nucleus of six women using the radiotracer [ ${ }^{11} \mathrm{C}$ ]NMSP. They observed a small trend in $\mathrm{k} 3$ values, with lower values in the follicular compared to luteal phase. Although NMSP also has high affinity for serotonin-2 receptors (Hall et al, 1990; Mach et al, 1993a), which somewhat complicates the conclusion that changes occurred solely in D2 receptor availability, more recent studies using $\left[{ }^{11} \mathrm{C}\right] \mathrm{NMSP}$ have demonstrated that the PET signal arising from the caudate nucleus and putamen is primarily due to occupancy of DA receptors (eg Lyon et al, 1986; Grunder et al, 1997). More recently, this group (Munro et al, 2006) examined differences in D2 availability as a function of menstrual cycle phase with $\left[{ }^{11} \mathrm{C}\right]$ raclopride, a ligand that is more selective for D2 receptors compared to NMSP (Hall and Wedel, 1986; Hall et al, 1990) and has a binding profile similar to $\left[{ }^{18} \mathrm{~F}\right] \mathrm{FCP}$ (Mach et al, 1997; Nader and Czoty, 2005). While they too found differences as a function of menstrual cycle (in the putamen but not caudate nucleus or ventral striatum), the effects were opposite to those reported by Wong et al (1988) and the present findings. Finally, Nordström et al (1998) reported that $\left[{ }^{11} \mathrm{C}\right]$ raclopride binding potential in the putamen was not influenced by menstrual cycle phase. There are several possible reasons for the discrepancies, including the smaller number of human subjects studied twice, that is, in both phases (three in the Nordström et al, 1998 study, none in the Munro et al, 2006 study) compared to the repeated-measures design with seven monkeys, and the use of drug-naive monkeys and a high-resolution microPET camera in the present study.

Although striatal DA D2 receptor availability declines with age (eg Wong et al, 1984, 1997; Rinne et al, 1993; Mukherjee et al, 2002), it is unlikely that age served as a confounding variable in this study. The average age of the 
monkeys was approximately 13, with a range of 9-17 years old. Female cynomolgus monkeys do not approach declining ovarian function and natural menopause until they are approximately 24-29 years of age (Appt, 2004). Although a previous study in humans (Pohjalainen et al, 1998) provided evidence for age-related changes in affinity of striatal D2-like receptors for $\left[{ }^{11} \mathrm{C}\right]$ raclopride, a large age range of subjects (19-82 years old) was used, including post-menopausal women. In the seven monkeys used in the present study, correlative analysis did not reveal significant relationships between age and D2 DVRs in the caudate nucleus or putamen.

Evidence of sex differences in drug abuse and affective disorders, particularly those that involve striatal DA function (eg Lukas et al, 1996; Becker et al, 2001; Staley et al, 2001; Caine et al, 2004), is accumulating. However, in vivo imaging studies to date have not examined sex differences in D2 receptor availability in non-human primates. Our laboratory has extensive experience imaging male monkeys. Although comparing such results with those of the present study is complicated by use of different PET cameras, we feel it is insightful to directly compare the present findings with those in males because the primary dependent variable, DVR, is a relative measure. Moreover, it is noteworthy that in previous PET studies in which male and female cynomolgus monkeys were studied using the same PET camera, DVRs in a large ROI covering the caudate nucleus and putamen were similar across sexes (Grant et al, 1998; Morgan et al, 2002). In individually housed, drug-naive male cynomolgus monkeys (Czoty et al, $2005)$, DVRs in the caudate nucleus $(2.42 \pm 0.39)$ were lower than those observed in females in either the follicular $(2.85 \pm 0.11)$ or luteal $(3.18 \pm 0.14)$ phase in the present study. Similarly, putamen DVRs were lower in males $(2.87 \pm 0.43)$ than females scanned during either phase (follicular, $3.07 \pm 0.14$; luteal, $3.42 \pm 0.18$ ). These findings suggest sex differences in the availability of striatal D2 receptors in drug-naive non-human primates, with D2 availability in males more similar to females studied during the follicular phase.

The effect of menstrual cycle phase on D2 receptor availability may have relevance for understanding sex differences in clinical features of psychiatric disorders. Women show differences in a number of aspects of schizophrenia compared to men, and accumulating evidence suggests that estrogen may play a protective role regarding vulnerability (for reviews see Grigoriadis and Seeman 2002; Hafner, 2003; Halbreich and Kahn, 2003). For example, a later age of onset of symptoms related to schizophrenia is observed in women (Aleman et al, 2003) and women generally respond to lower doses of medications that target D2 receptors compared to men (Seeman, 1983). Moreover, schizophrenic symptoms, generally less severe in women (Hafner, 2003), frequently worsen when estrogen is low (Hallonquist et al, 1993). Although the mechanisms by which estrogen and striatal D2 function interact with symptoms and therapeutic efficacy are not fully understood, the present study suggests that the effectiveness of medications which target D2 receptors may differ across the menstrual cycle phase.

Menstrual cycle-related fluctuations in D2 receptor availability may also underlie sex differences in clinical aspects of drug abuse. Although PET imaging studies have not always reported sex differences in basal levels of D2 receptor availability, it is possible that sex differences may emerge in the presence of a drug. For example, although Munro et al (2006) observed similar basal availability of D2 receptors in women and men, amphetamine-induced DA release was significantly greater in men. In light of the apparent inverse relationship between D2 receptor availability and vulnerability to abuse-related effects of cocaine (Volkow et al, 1990; Thanos et al, 2001; Morgan et al, 2002; Nader and Czoty, 2005; Nader et al, 2006), the present results suggest that sensitivity to the abuse-related effects of psychostimulants may vary with menstrual cycle phase. Supporting this hypothesis, Mello et al (2007) reported that a low cocaine dose was a stronger reinforcer during follicular $v s$ luteal phase in monkeys self-administering cocaine under a progressive-ratio schedule of reinforcement. An additional hypothesis suggested by these data is that sensitivity to psychostimulants will be higher in males than in females, but females will be more similar to males during the follicular phase than during the luteal phase. Supporting this hypothesis, the majority of studies in humans report greater subjective effects of cocaine and amphetamine in females during the follicular phase (Justice and de Wit, 1999; White et al, 2002; for review see Terner and de Wit, 2006). Although a greater proportion of cocaine abusers are males (SAMHSA, 2006), specific sex differences and the neurobiological and sociocultural factors that produce them have not been fully elucidated (eg Wagner and Anthony, 2007) and studies of sex differences in drug self-administration in laboratory animals have produced inconsistent results (for review see Lynch et al, 2002). The present data suggest that the influence of menstrual cycle phase could partially explain discrepancies in previous studies of sex differences in neuropsychiatric diseases and drug responsiveness, and should be taken into account in future studies.

\section{ACKNOWLEDGEMENTS}

We thank Kimberly Black, Robert Gould, Michelle Icenhower, and Stephanie Rideout for excellent technical assistance. This research was supported by NIDA Grant DA 017763 (MAN) and a pilot grant from the Center for Biomolecular Imaging at Wake Forest University School of Medicine.

\section{DISCLOSURE/CONFLICT OF INTEREST}

We declare that there are no conflicts of interest for any of the authors.

\section{REFERENCES}

Aleman A, Kahn RS, Selten JP (2003). Sex differences in the risk of schizophrenia: evidence from meta-analysis. Arch Gen Psychiatry 60: $565-571$.

Appt SE (2004). Usefulness of the monkey model to investigate the role soy in postmenopausal women's health. ILAR J 45: 200-211.

Bazzett TJ, Becker JB (1994). Sex differences in the rapid and acute effects of estrogen on striatal D2 dopamine receptor binding. Brain Res 637: 163-172. 
Becker JB (1999). Gender differences in dopaminergic function in striatum and nucleus accumbens. Pharmacol Biochem Behav 64: 803-812.

Becker JB, Molenda H, Hummer DL (2001). Gender differences in the behavioral responses to cocaine and amphetamine. Implications for mechanisms mediating gender differences in drug abuse. Ann NY Acad Sci 937: 172-187.

Bogetto F, Venturello S, Albert U, Maina G, Ravizza L (1999). Gender-related clinical differences in obsessive-compulsive disorder. Eur Psychiatry 14: 434-441.

Caine SB, Bowen CA, Yu G, Zuzga D, Negus SS, Mello NK (2004). Effect of gonadectomy and gonadal hormone replacement on cocaine self-administration in female and male rats. Neuropsychopharmacology 29: 929-942.

Cross AJ, Crow TJ, Owen F (1981). 3H-Flupenthixol binding in postmortem brains of schizophrenics: evidence for a selective increase in dopamine D2 receptors. Psychopharmacology 74: 122-124.

Cyr M, Calon F, Morissette M, Di Paolo T (2002). Estrogenic modulation of brain activity: implications for schizophrenia and Parkinson's disease. J Psychiatry Neurosci 27: 12-27.

Czoty PW, Gage HD, Nader MA (2005). PET imaging of striatal dopamine D2 receptors in non-human primates: increases in availability produced by chronic raclopride treatment. Synapse 58: $215-219$.

Dazzi L, Seu E, Cherchi G, Barbieri PP, Matzeu A, Biggio G (2007). Estrus cycle-dependent changes in basal and ethanol-induced activity of cortical dopaminergic neurons in the rat. Neuropsychopharmacology 32: 892-901.

Dewey SL, Smith GS, Logan J, Brodie JD, Yu DW, Ferrieri RA et al (1992). GABAergic inhibition of endogenous dopamine release measured in vivo with 11C-raclopride and positron emission tomography. J Neurosci 12: 3773-3780.

Di Paolo T (1994). Modulation of brain dopamine transmission by sex steroids. Rev Neurosci 5: 27-41.

Di Paolo T, Falardeau P, Morissette M (1988). Striatal D-2 dopamine agonist binding sites fluctuate during the rat estrous cycle. Life Sci 43: 655-672.

Di Paolo T, Levesque D, Daigle M (1986). A physiological dose of progesterone affects rat striatum biogenic amine metabolism. Eur J Pharmacol 125: 11-16.

Evans SM, Fischman MW, Folitn RW (2002). The effects of smoked cocaine during the follicular and luteal phases of the menstrual cycle in women. Psychopharmacology 159: 397-406.

Evans SM, Foltin RW (2006). Exogenous progesterone attenuates the subjective effects of smoked cocaine in women, but not in men. Neuropsychopharmacology 31: 158-167.

Fahey FH, Gage HD, Buchheimer N, Smith HC, Harkness BA, Williams RC et al (2004). Evaluation of the quantitative capacity of a high-resolution PET scanner for small animal imaging. J Comput Assist Tomogr 28: 842-848.

Farde L, Hall H, Pauli S, Halldin C (1995). Variability in D2dopamine receptor density and affinity: a PET study with $\left[{ }^{11} \mathrm{C}\right]$ raclopride in man. Synapse 20: 200-208.

Ginovart N, Farde L, Halldin C, Swahn CG (1997). Effect of reserpine-induced depletion of synaptic dopamine on $\left[{ }^{11} \mathrm{C}\right]$ raclopride binding to D2-dopamine receptors in the monkey brain. Synapse 25: 321-325.

Goodman AJ, Descalzi CD, Johnson DK, Hodgen GD (1977). Composite pattern of circulating LH, FSH, estradiol, and progesterone during the menstrual cycle in cynomolgus monkeys. Proc Soc Exp Biol Med 155: 479-481.

Grant KA, Shively CA, Nader MA, Ehrenkaufer RL, Line SW, Morton TE et al (1998). Effect of social status on striatal dopamine D2 receptor-binding characteristics in cynomolgus monkeys assessed with positron emission tomography. Synapse 29: 80-83.

Grigoriadis S, Seeman MV (2002). The role of estrogen in schizophrenia: implications for schizophrenia practice guidelines for women. Can J Psychiatry 47: 437-442.
Grunder G, Yokoi F, Offord SJ, Ravert HT, Dannals RF, Salzman JK et al (1997). Time course of 5-HT2A receptor occupancy in the human brain after a single oral dose of the putative antipsychotic drug MDL 100,907 measured by positron emission tomography. Neuropsychopharmacology 17: 175-185.

Guttman M, Seeman P (1985). L-dopa reverses the elevated density of D2 dopamine receptors in Parkinson's diseased striatum. J Neural Transm 64: 93-103.

Hafner H (2003). Gender differences in schizophrenia. Psychoneuroendocrinology 28(Suppl 2): 17-54.

Halbreich U, Kahn LS (2003). Hormonal aspects of schizophrenias: an overview. Psychoneuroendocrinology 28(Suppl 2): 1-16.

Hall H, Wedel I (1986). Comparisons between the in vitro binding of two substituted benzamides and two butyrophenones to dopamine-D2 receptors in the striatum. Acta Pharmacol Toxicol 58: $368-373$.

Hall H, Wedel I, Halldin C, Kopp J, Farde L (1990). Comparison of the in vitro receptor binding properties of $\mathrm{N}-[3 \mathrm{H}]$ methylspiperone and $[3 \mathrm{H}]$ raclopride to rat and human brain membranes. J Neurochem 55: 2048-2057.

Hallonquist JD, Seeman MV, Lang M, Rector NA (1993). Variation in symptom severity over the menstrual cycle of schizophrenics. Biol Psychiatry 33: 207-209.

Hendrick V, Altshuler LL, Burt VK (1996). Course of psychiatric disorders across the menstrual cycle. Harv Rev Psychiatry 4: 200-207.

Hesse S, Muller U, Lincke T, Barthel H, Villmann T, Angermeyer MC et al (2005). Serotonin and dopamine transporter imaging in patients with obsessive-compulsive disorder. Psychiatry Res 140: 63-72.

Jewitt DA, Dukelow WR (1972). Cyclicity and gestation length of Macaca fascicularis. Primates 13: 327-330.

Jovanovic H, Cerin A, Karlsson P, Lundberg J, Halldin C, Nordstrom AL (2006). A PET study of $5-\mathrm{HT}_{1 \mathrm{~A}}$ receptors at different phases of the menstrual cycle in women with premenstrual dysphoria. Psychiatry Res: Neuroimaging 148: 185-193.

Justice AJ, de Wit H (1999). Acute effects of d-amphetamine during the follicular and luteal phase of the menstrual cycle in women. Psychopharmacology 145: 67-75.

Laruelle M (2000). Imaging synaptic neurotransmission with in vivo binding competition techniques: a critical review. J Cereb Blood Flow Metab 20: 423-451.

Leranth C, Roth RH, Elswoth JD, Naftolin F, Horvath TL, Redmond Jr DE (2000). Estrogen is essential for maintaining nigrostriatal dopamine neurons in primates: implications for Parkinson's disease and memory. J Neurosci 20: 8604-8609.

Logan J, Fowler JS, Volkow ND, Wolf AP, Dewey SL, Schlyer DJ et al (1990). Graphical analysis of reversible radioligand binding from time-activity measurements applied to $\left[\mathrm{N}-{ }^{11} \mathrm{C}\right.$-methyl](-)-cocaine PET studies in human subjects. J Cereb Blood Flow Metab 10: 740-747.

Lukas SE, Sholar M, Lundahl LH, Lamas X, Kouri E, Wines JD et al (1996). Sex differences in plasma cocaine levels and subjective effects after acute cocaine administration in human volunteers. Psychopharmacology 125: 346-354.

Lynch WJ (2006). Sex differences in vulnerability to drug self-administration. Exp Clin Psychopharmacol 14: 34-41.

Lynch WJ, Roth ME, Carroll ME (2002). Biological basis of sex differences in drug abuse: preclinical and clinical studies. Psychopharmacology 164: 121-137.

Lyon RA, Titeler M, Frost JJ, Whitehouse PJ, Wong DF, Wagner Jr $\mathrm{HN}$ et al (1986). ${ }^{3} \mathrm{H}-3-\mathrm{N}$-methylspiperone labels D2 dopamine receptors in basal ganglia and S2 serotonin receptors in cerebral cortex. J Neurosci 6: 2941-2949.

Mach RH, Elder ST, Morton TE, Nowak PA, Evora PH, Scripko JG et al (1993a). The use of [18F]4-fluorobenzyl iodide (FBI) in PET radiotracer synthesis: model alkylation studies and its 
application in the design of dopamine D1 and D2 receptor-based imaging agents. Nucl Med Biol 20: 777-794.

Mach RH, Luedtke RR, Unsworth CD, Boundy VA, Nowak PA, Scripko JG et al (1993b). 18F-labeled benzamides for studying the dopamine D2 receptor with positron emission tomography. J Med Chem 36: 3707-3720.

Mach RH, Nader MA, Ehrenkaufer RL, Line SW, Smith CR, Gage HD et al (1997). Use of positron emission tomography to study the dynamics of psychostimulant-induced dopamine release. Pharmacol Biochem Behav 57: 477-486.

Mach RH, Nader MA, Ehrenkaufer RL, Line SW, Smith CR, Luedtke RR et al (1996). Comparison of two fluorine-18 labeled benzamide derivatives that bind reversibly to dopamine D2 receptors: in vitro binding studies and positron emission tomography. Synapse 24: 322-333.

Mello NK, Knudson IM, Mendelson JH (2007). Sex and menstrual cycle effects on progressive ratio measures of cocaine self-administration in cynomolgus monkeys. Neuropsychopharmacology 32: 1956-1966.

Morgan D, Grant KA, Gage HD, Mach RH, Kaplan JR, Prioleau O et al (2002). Social dominance in monkeys: dopamine D2 receptors and cocaine self-administration. Nat Neurosci 5: 169-174.

Mukherjee J, Christian BT, Dunigan KA, Shi B, Narayanan TK, Satter M et al (2002). Brain imaging of 18F-fallypride in normal volunteers: blood analysis, distribution, test-retest studies, and preliminary assessment of sensitivity to aging effects on dopamine D-2/D-3 receptors. Synapse 46: 170-188.

Munro CA, McCaul ME, Wong DF, Oswald LM, Zhou Y, Brasic J et al (2006). Sex differences in striatal dopamine release in healthy adults. Biol Psychiatry 59: 966-974.

Nader MA, Czoty PW (2005). PET imaging of dopamine D2 receptors in monkey models of cocaine abuse: genetic predisposition $v s$ environmental modulation. Am J Psychiatry 162: 1473-1482.

Nader MA, Czoty PW (2008). Brain imaging in non-human primates: insights into drug addiction. ILAR J 49: 89-102.

Nader MA, Grant KA, Gage HD, Ehrenkaufer RL, Kaplan JR, Mach RH (1999). PET imaging of dopamine D2 receptors with $\left[{ }^{18} \mathrm{~F}\right]$ fluoroclebopride in monkeys: effects of isoflurane- and ketamine-induced anesthesia. Neuropsychopharmacology 21: 589-596.

Nader MA, Morgan D, Gage HD, Nader SH, Calhoun TL, Buchheimer $\mathrm{N}$ et al (2006). PET imaging of dopamine D2 receptors during chronic cocaine self-administration in monkeys. Nat Neurosci 9: 1050-1056.

Nordström AL, Olsson H, Halldin C (1998). A PET study of D2 dopamine receptor density at different phases of the menstrual cycle. Psychiatry Res 83: 1-6.

Pazos A, Stoeckel ME, Hindelang C, Palacios JM (1985). Autoradiographic studies on dopamine D2 receptors in rat pituitary: influence of hormonal states. Neurosci Lett 59: 1-7.

Pohjalainen T, Rinne JO, Nagren K, Syvalahti E, Hietala J (1998). Sex differences in the striatal dopamine D2 receptor binding characteristics in vivo. Am J Psychiatry 155: 768-773.

Reiman EM, Armstrong SM, Matt KS, Mattox JH (1996). The application of positron emission tomography to the study of the normal menstrual cycle. Human Reprod 11: 2799-2805.

Rinne JO, Hietala J, Ruotsalainen U, Sako E, Laihinen A, Nagren K et al (1993). Decrease in human striatal dopamine D2 receptor density with age: a PET study with $\left[{ }^{11} \mathrm{C}\right]$ raclopride. J Cereb Blood Flow Metab 13: 310-314.

Seeman MV (1983). Interaction of age, sex and neuroleptic dose. Compr Psychiatry 24: 125-128.

Seeman MV (1996). Schizophrenia, gender and affect. Can J Psychiatry 41: 263-264.
Seeman MV, Lang M (1990). The role of estrogens in schizophrenia gender differences. Schizophr Bull 16: 185-194.

Sofuoglu M, Dudish-Poulsen S, Nelson D, Pentel PR, Hatsukami DK (1999). Sex and menstrual cycle differences in the subjective effects from smoked cocaine in humans. Exp Clin Psychopharmacol 7: 274-283.

Smith YR, Zubieta JK, del Carmen MG, Dannals RF, Ravert HT, Zacur HA et al (1998). Brain opioid receptor measurements by positron emission tomography in normal cycling women: relationship to luteinizing hormone pulsatility and gonadal steroid hormones. J Clin Endocrinol Metab 83: 4498-4505.

Staley JK, Krishnan-Sarin S, Zoghbi S, Tamagnan G, Fujita M, Seibyl JP et al (2001). Sex differences in $\left[{ }^{123} \mathrm{I}\right] \beta$-CIT SPECT measures of dopamine and serotonin transporter availability in healthy smokers and nonsmokers. Synapse 41: 275-284.

Substance Abuse and Mental Health Services Administration (2006). Results from the 2005 National Survey on Drug Use and Health: National Findings (Office of Applied Studies, NSDUH Series H-30, DHHS Publication No. SMA 06-4194). Rockville, MD, www.oas.samhsa.gov/NSDUH/2K5NSDUH/ 2K5results.htm (accessed 01/23/2008).

Tai C, Chatziioannou A, Siegel S, Young J, Newport D, Goble RN et al (2001). Performance evaluation of the microPET P4: a PET system dedicated to animal imaging. Phys Med Biol 46: 1845-1862.

Terner JM, de Wit H (2006). Menstrual cycle phase and responses to drugs of abuse in humans. Drug Alcohol Depend 84: 1-13.

Thanos PK, Volkow ND, Freimuth P, Umegaki H, Ikari H, Roth G et al (2001). Overexpression of dopamine $\mathrm{D}_{2}$ receptors reduces alcohol self-administration. J Neurochem 78: 1094-1103.

Tolson D, Fleming V, Schartau E (2002). Coping with menstruation: understanding the needs of women with Parkinson's disease. J Adv Nurs 40: 513-521.

Volkow ND, Fowler JS, Wang GJ, Hitzemann R, Logan J, Schlyer DJ et al (1993). Decreased dopamine D2 receptor availability is associated with reduced frontal metabolism in cocaine abusers. Synapse 14: 169-177.

Volkow ND, Fowler JS, Wolf AP, Schlyer D, Shiue CY, Alpert R et al (1990). Effects of chronic cocaine abuse on postsynaptic dopamine receptors. Am J Psychiatry 147: 719-724.

Wagner FA, Anthony JC (2007). Male-female differences in the risk of progression from first use to dependence upon cannabis, cocaine and alcohol. Drug Alcohol Depend 86: 191-198.

White TL, Justice AJ, de Wit H (2002). Differential subjective effects of d-amphetamine by gender, hormone levels and menstrual cycle phase. Pharmacol Biochem Behav 73: 729-741.

Wieck A, Davies RA, Hirst AD, Brown N, Papadopoulos A, Marks $\mathrm{MN}$ et al (2003). Menstrual cycle effects on hypothalamic dopamine receptor function in women with a history of puerperal bipolar disorder. J Psychopharmacol 17: 204-209.

Wilson ME (1998). Premature elevation in serum insulin-like growth factor-I advances first ovulation in rhesus monkeys. J Endocrinol 158: 247-257.

Wong DF, Broussolle EP, Wand G, Villemagne V, Dannals RF, Links JM et al (1988). In vivo measurement of dopamine receptors in human brain by positron emission tomography. Age and sex differences. Ann NY Acad Sci 515: 203-214.

Wong DF, Wagner Jr HN, Dannals RF, Links JM, Front JJ, Ravert HT et al (1984). Effects of age on dopamine and serotonin receptors measured by positron tomography in the living human brain. Science 226: 1393-1396.

Wong DF, Young D, Wilson PD, Meltzer CC, Chan B, Dannals RF et al (1997). Quantification of neuroreceptors in the living human brain. III. D2-like dopamine receptors. Theory, validation and results of normal aging. J Cereb Blood Flow Metab 17: 316-330. 